\title{
Women In The Folk Literature Of Sindh: Re-Examining The Poetry Of Shah Abdul Latif Bhitai
}

\author{
Bashir Ahmed \\ Department of General History \\ University of Sindh \\ Humera Naz \\ Department of General History \\ University of Karachi
}

\begin{abstract}
This article is an attempt to examine the significance of folk literature which embodies the history, tradition and culture; implies a socio-cultural corpus specific to a particular ethnic group, and includes folk-behavior or the study of the specific customs and beliefs of a given social group and folk life or the study of folk-traditions. The folk literature of Sindh, like all other folk literature is the result of an interaction of cultural, geographical and religious factors that offers valuable historical evidence of cultural influence. Shah Abdul Latif Bhitai (1689- 1752 CE) is a celebrated Sufi poet, philosopher and social reformist, who employed folklore as a major segment in his poetry. The collection of Bhitai's poetry which mostly comprised of the folklore is titled Shah Jo Risalo. This paper deals with a socio-cultural analysis of the folklore as a source for providing an image of the woman in the society. The Sindhi folklore also depicts an interesting picture of the prevailing customs and traditions. This article deals with a critical approach in order to reveal some historical truth in this regard.
\end{abstract}

Keywords: Folklore, Sindh, Woman, History, Culture, Society.

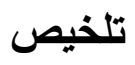

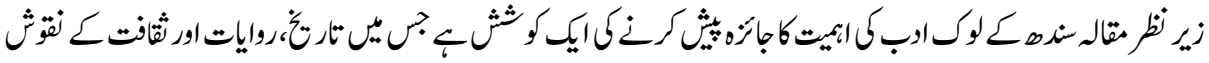

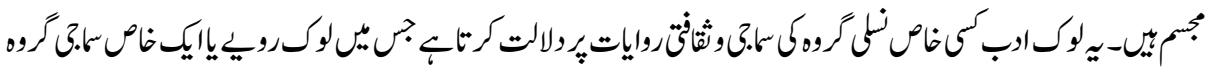

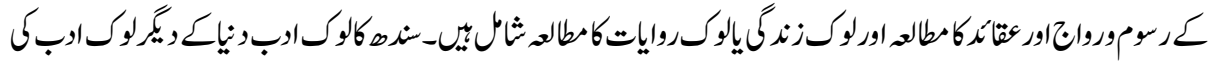

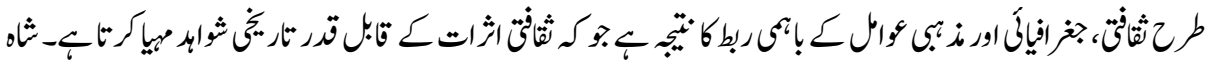

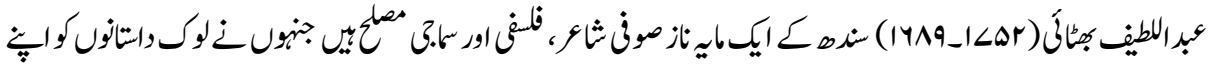

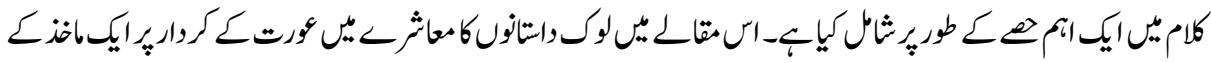

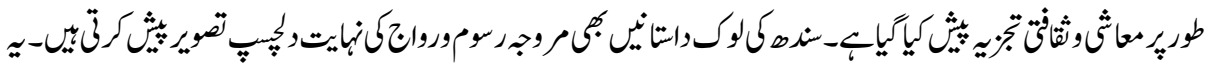

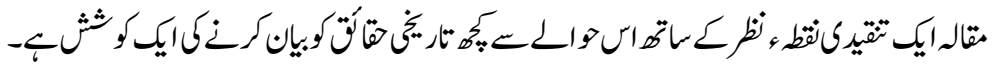

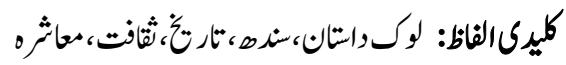




\section{Introduction}

Folk literature based on folklore or oral tradition, is the lore (traditional knowledge and beliefs) of culture. It is initially transmitted by word of mouth and consists, as does written literature, of both prose and verse narratives, poems and songs, myths, dramas, rituals, proverbs, riddles, and the like. Nearly all known people of different regions and cultures, now or in the past, have produced it.

Almost all the world literature, since the dawn of civilization has been folklore until the years between 4000 and 3000 BCE, when writing was developed in Egypt and in the Mesopotamian civilization in Sumer. Over centuries, a vast record of written literature produced in the form of hand-written manuscripts to paper print, though alongside this exists the lore of people, the observations, experiences and sentiments of the common people expressed through the folklore. A minor difference between folk and academic history is to be found in the medium of communication. In oral history, it is difficult to preserve the unmemorable; the jumble of dull detail and fine webs of qualification that make written arguments seem complex and convincing, do not belong in good tales (Glassie, 1987). The genesis of the Odyssey of Homer in Greece, the Shahnamah of Firdausi, a great world epic of Iran and the Divine Comedy by Dante in Italy has been rightly traced back to the oral traditions.

The folk literature includes the narrations which have some geo-historical basis. In them, names of some persons and places and references to some events and occurrences could be identified historically (Baloch, 2014). These may be pseudo-historical or historical. Adventure, romance and intrigue are among their more conspicuous elements. Folklore usually reclaims from the historical past which is more exciting and romantic, and use it after diluting it with its own unbelievable. Each folklore has its geographical habitat and a background in history. The folk literature includes "the study of antiquities or archaeology, embracing everything relating to ancient customs and usages, notions, beliefs and superstitions of the common people. It is the science which treats the survival of archaic belief and customs in modern age" (Saleem, 2004). They play a dominant role in literature and need not to have an intellectual, philosophical, religious or a humorous motive, but none of these subjects is ever ruled out. Literature holds a mirror to life and is the criticism of life. In fact, it shows life in miniature and also means of "the common man without any tempering by artificiality, or conscious efforts of any artist” (Allana, 1977).

Likewise the other regions of the world, Pakistan also has a wide variety of folklore, mostly circulated regionally. However, certain tales have related variants in other regions of the country or in neighboring countries. The region forming modern Pakistan was home to the ancient Indus Valley Civilization and then, successively, recipient of ancient Vedic, Persian, Indo-Greek and Islamic cultures. The area has witnessed invasions and/or 
settlement by the Aryans, Persians, Greeks, Arabs, Turks, Afghans, Mongols and the British (Doctor, 1985). For this reason, Pakistani folklore contains elements of all of these cultures. The themes, characters, heroes and villains of regional folklore are often a reflection of local religious traditions, and folklore serves as both entertainment and a vehicle for transmission of moral and religious concepts and values. Some folklore performances are integral to religious rites and festivals.

\section{Folklore of Sindh}

In the region of Pakistan, the province of Sindh in the south is equally rich in folklore. Sindhi folklore is the folk tradition which has developed in Sindh over a number of centuries. Sindhi mythology here means the myths and sacred narratives of the culturally and linguistically related groups of ancient people who inhabited the ancient Sindh and its borderlands. Sindh abounds with folklore, in all forms, and colors from such obvious manifestations.

Yet the folklore of Sindh, like all other folklore is the result of an interaction of cultural, geographical and religious factors and offers valuable historical evidence of cultural influence (Doctor, 1985). It is a very important historical source in such a region as Sindh where there was no tradition of recording important events in writing till the fifteenth century (Khan, 1959). The oral testimonies were introduced in Sindh during the last days of the Arab rule (in the eleventh century CE) and the successive Soomra period, particularly in the form of folklore.

The earliest record of Sindhi literature and written folklore dates back to the Soomra period (1050-1350 CE), when Sindhi became the common language of lore and verbal narration. This period is regarded as the 'romantic period' of the history of Sindh, which gave birth to patriotism and folk-literature (Baloch, 2003). The local Soomra rule in Sindh's history holds extraordinary significance in terms of intellectual awakening among the masses. It originated eminent stages and rhapsodists (local Bhats and Charans), who memorized the historical, regional and traditional folktales and folk-stories. They laid foundation for Sindhi folk literature by composing and popularizing the classical narrations of chivalry and legendry romances, prevalent with the folk in prose and poetry.

Thus, a number of folklore became popular among the people such as Umar-Marui, Moomal-Rano, Sohni-Mahiwal, Saif al-Maluk-Badi al-Jamal, Leela-Chanesar, SorathRai Diyach, Sassui-Pannun and Noori-Jam Tamachi etc. This folklore provided foundation to history writing in Sindh. Beside the folklore, there are some famous epics and ballads such as the battles between the Soomras and the Gujjars; Ala al-Din Khilji and the Jams (Baloch, 1999). There are also some local ballads such as Dodo-Chanesar. These are very important semi-historical sources in such a region as Sindh where we found no written history till the fifteenth century (Khan, 1959). 
Folklore is considered as the semi-historical material and is the only source to bring the historical facts to light. Folklore was preserved orally for centuries by local Bhats and Charans. Shah Jo Risalo (Poetry of Shah Abdul Latif Bhitai) is regarded as the Magnum Opus of the folk literature produced in Sindh. Shah Abdul Latif Bhitai (1689-1752 CE), a Sufi scholar and saint, is considered one of the greatest poets of the Sindhi language. His most famous work, the 'Shah Jo Risalo', is a compilation of folk-tales and legends in verse. The original work was orally transmitted and became popular in the folk-culture of Sindh.

The women of Shah Abdul Latif's poetry are known as the Seven Queens, heroines of Sindhi folklore, who have been given the status of royalty in the 'Shah Jo Risalo'. They are featured in the tales of Umar-Marui (Marui), Moomal-Rano (Moomal), SohniMahiwal (Sohni), Leela-Chanesar (Leela), Sorath Rai Diyach (Heer), Sassui-Pannun (Sassui) and Noori-Jam Tamachi (Noori). These women are celebrated throughout Sindh for their positive qualities: honesty, integrity, piety, and loyalty. They are also valued for their bravery and willingness to risk their lives in the name of love.

Shah Abdul Latif Bhitai's Shah Jo Risalo deals much with the social and cultural conditions in the eighteenth-century Sindh. The collection of Bhitai's poetry is titled Shah Jo Risalo, which contains different surs (musical tunes) and verses. Shah Jo Risalo is considered as the Bible by most people in Sindh. The work contains great lessons for every segment of the society. Bhitai's poetry addresses people belonging to various walks of life, the marginalized segments of society, poor folks, and menial workers such as potters, blacksmiths, washer-men, fishermen, shepherds, and cloth-makers. It also throws light on various aspects of the life as well as the social, cultural, political and religious issues. It provides great insight into the society, its structures, values, norms, culture and its varied expressions. It also deals with the romantic folk tales of Sindh and its neighboring regions. Though he was born in an elite and influential family in Sindh, he renounced his inherited social association, and expressed his solidarity with the oppressed classes. At the time of his birth, great social and political transition had begun. It continued throughout his life time. These developments adversely affected the socioeconomic conditions, and increased the gap between the rich and the poor. (Sorley, 1989)

The social conditions of Sindh were very critical during the eighteenth century. Civil wars were there due to the weakening of the central authority of the Mughals, and the power struggle between petty landlords to gain power. Consequently, the common people of Sindh became vulnerable in social terms. The war between Kalhoras and Talpurs in $1775 \mathrm{CE}$ further weakened the social fabric of the society. The British East India Company had also stopped its trade with Sindh. Meanwhile in $1780 \mathrm{CE}$, the Afghans attacked Sindh under the command of Madad Khan. He looted and plundered the Sindhis. Despite these political upheavals, Sindh produced eminent scholars who contributed much to the various branches of knowledge. (Shadai, 1985) 
Bhitai lived among the common people, and since he had a sensitive soul, he felt the miseries and sufferings of the people. He was a great social analyst as well, who analyzed social behaviour of the people, and it was reflected in his poetry as well. It is a fact that Bhitai's poetry was the first great attempt to understand the feelings of the common people in a language that Muslim and Hindu could understand. He was the first successful poet who has spoken a language which everybody could accept not simply as literature or highly artificial construction of words but as something that everyone felt. (Syed, 1988)

In the eighteenth century, the society in Sindh was male dominated. Man was considered to be superior than woman, however, in Shah Jo Risalo, Bhitai highlighted many qualities and characteristics of women. Once he went to Jaisalmir, where he observed women's hardship and wrote that:

"The women of Jaisalmir deserve all praises, Because they allowed themselves to sacrifice their rights in the name of Allah" (Syed, 1988: 9)

In Risalo, Bhitai represents woman as a symbol of patriotism, spirituality, and courage. She also symbolizes bravery as well as the soul of a seeker of the path of Sufism. The heroines of Bhitai's folk tales like Sasui, Marui and Suhni are symbols of courage and bravery, as well as the sufis. Bhitai has pointed out the strength of woman and her determination that she can cross the mountain in search of her beloved. It symbolizes the search of a soul to find the real Beloved, i.e. the Divine. He writes:

"There is no other God but He, misfortunes are all ordained Say "no trouble comes to your, save what He ordains" Luck or ill luck to Marui is the same." (Khamisani, 1975: 172)

Another place, Bhitai states:

"I neither found mountains in the world nor yearning for Baloch, All sufferings was for Sasui, gone was it when Punhoon I became" (Khamisani, 1975: 104)

Bhitai had selected many local folktales and folksongs from different regions like Sindh, Punjab, Rajasthan, and Balochistan (Sanai, 2012). He had employed them in a way that his ideas can be understood easily by the ordinary people. Bhitai acknowledged the role of women, and highlighted how the women contributed to improve the status of the oppressed and marginalized section of society. One of the heroines in his folktales is Noori, who is a fisherwoman by caste, but the ruler Jam Tamachi loved her (Damraho, 2007). So she asked the ruler to exempt the poor people from undue taxes: 
"You are ruler Tamachi, me poor Gundri maid, I am your spouse; let my people go free of tax" (Khamisani, 1975: 185)

Bhitai has unlimited admiration for women. In Sur Sasui, Latif presented Sasui as the sign of bravery, will power and struggle. In Sur Suhni, he depicted Suhni as a bold woman who did not hesitate to break predominant traditions. Moreover, in Sur Kamode, he portrayed Noori as an obedient woman who shows her thankfulness to King Tamachi, who accepted her as his queen despite the fact that Noori belonged to a low caste of fishermen (Damraho, 2007).

Bhitai's poetry throws light on the deprived people of the society including the women. His poetry provides hope and encouragement to the oppressed women. He gave them solace in his poetry to strive hard and be bold in order to confront the problems and challenges of the day:

"By giving up avarice, greed and clothing, set out for the desired goal, Success with the beloved cannot be achieved merely by sleeping." (Syed, 1988: 74)

Bhitai advised and warned the women in general and the wives of sailors in particular, of the forthcoming dangers (Syed, 1998). It shows his concern for the women, who were understood as a weak segment of the society. The following stanza or Sur Samundi reflects the picture of the Bhitai's advices and encouragement for the women during the difficult times as he writes:

"O mother! Stay beside the rope of the seafarers, Lest they should sail away in their boats causing you heartache" (Syed, 1988: 75)

The privileged classes under Kalhora rule included the royal family, landlords (jagirdars and zamindars), the Syeds (the descendants of the Holy Prophet PBUH), the spiritual guides or the pirs, and the Baloch tribal chiefs. In Sindh, the term jagir has been used to cover a large number of different types of land holdings. The jagirdars held land either entirely free or on payment of a small rent. They were entitled to conduct the land assessment. Moreover, these privileged classes were exempted from paying tax to the state. They enjoyed all the facilities and privileges from the rulers. In return, they provided the support to the rulers. (Syed, 1988)

Aari Jam was a king of Kech Makran. He had a son named Punhal, who started his business journey from Kech to Bambhor. At Bambhor, he met with Sasui, and fell in her love. Sasui was born in a Hindu family, and upon her birth, the priests predicted that one day she would marry a Muslim. Upon hearing that, her parents put her in a wooden box 
and threw her into water. The box reached Bambhor, where there lived a washer man named Muhammad. He found the box and brought her up. So she became a dhoban (cloth-washerwoman) by caste. Though Punhoon was a son of king and affluent businessman, he washed cloth with the father of Sasui in order to acquire her. He forgot his status, and gave up his pomp and show. He started living the life of poor, trying to acquire Sasui. Sasui knew that her caste was low and Punhoon was rich and Baloch by caste (Damraho, 2007). Bhitai highlights it in Risalo in the words of Sasui as:

"I am a humble washerwoman, for unworthy me, Punhoon became a washer man.” (Khamisani, 1975: 123)

"My caste's news must not reach Kech, Lest Punhoon in public feels ashamed" (Khamisani, 1975: 143)

Furthermore, Sasui realised the class difference between her and her lover. She felt that her in-laws would feel uncomfortable due to her low social status. She was afraid of her in-laws and the people of Makran that they might see Punhoon working as a manual worker. Bhitai has expressed her thoughts when brothers of Punhoon took him away from her. They left Sasui and abducted Punhoon.

"With other washer men, Punhoon did the clothes wash, There came a messenger from Ari Jam, Oh Sardar! It least beloved you to strike the clothes with force." (Khamisani, 1975: 123)

"Did my brothers-in-laws think me a mere mistress? I cooked not delicious dishes to their taste, Neither did I gather friends who would for them dance, I did not comply with the custom of our clan, Mother! I lack much, Baloch's words I find of much worth." (Khamisani, 1975: 102)

In another folktale, Aagro was a local ruler of Bilhaar area, who was Jasodan by caste. He was an affluent when Lakes Daaki and Dhor irrigated his area. The lakes were not merely the source for irrigation but the livelihood for fishermen. As the water of the lakes dried up, it could not irrigate the area, and therefore, people of that area who were largely dependent upon agriculture and fish, migrated to other areas. Hence, the power and authority of Jasodan vanished away. In this regard, Bhitai has highlighted how nature affects the social and political conditions, and the life of the people as:

"The fisherman knew that branch's water would not be the same, They sailed with their boats away from that place, Causing worry to prosperous merchants and business man" (Khamisani, 1975: 277) 
Jam Odhar Samo was the son of Sakhi Daatar. Odhar supported Jam Abro and fought with the army of the Delhi Sultan, Ala al-Din Khalji (1296-1316). The army of Alauddin killed Dodo Soomro, who was another local ruler of Sindh. After the death of Dodo, his women were migrating to Kash. When they reached in the territory controlled by Odhar, he acted as a host and gave them shelter. At that time, everyone in Sindh was afraid of the Delhi army, and no one was ready to be host of the refugees. He became host of those women despite his mother strongly opposed and warned him of the wrath of the army of Ala al-Din. He refused to obey his mother, and preferred to die. He explained the meaning of his name - the protector - to his mother. Ultimately, he was killed by the army of Ala al-Din after fighting for ten days. Bhitai appreciated him in Sur Bilawal that he gave his life to honor the social norms and values as:

"You are our protector, our refuge, our leader, you are our hope in the world, our goal in the hereafter, Those helpless ones whom you protect, need pay no tax." (Khamisani, 1975: 288)

Local ruler named Jaam Tamachi was a Samma by caste. Feroz al-Din Jam Unar was his father, who was also a king. Tamachi was arrested by Jaam Juno and sent him to Delhi where Sultan Feroz Shah Tughluq (1355-88 CE) ruled. He came back to Sindh after the death of Sultan Feroz Shah, and became a ruler. Once he visited the popular Lake Keenjhar where he saw Noori. Noori was low caste fisher woman. He fell in love with her and got married with her. Noori was very humble and polite lady. She became queen but was still afraid of other wives of Tamachi as well as her in-laws.Despite his high social status, Tamachi even used to catch fish with her relatives in the lake. He often used to spare his time at Lake Kenjhar (Palijo 2015). The tombs of both of them are situated at Makli graveyard near Thatta. Bhitai discusses it in these words:

"You are Samo king, I fisher-maid with many defects, seeing your queens let me not be of your nearness bereft."

"You are the ruler Tamachi, I am a fisher maid, Think not of leaving one, whom you have wed."

"You are ruler Tamachi, me poor Gundri maid, I am your spouse; let my people go free of tax."

"All Samo queens adorned themselves to win the king, but he freely moves midst men who catch fish.” (Khamisani, 1977: 184-187)

In another romantic folktale of Moomal Rano, Bhitai highlighted the issue of caste and class distinctions. Raja Nand of Gujjar family was the ruler of Mirpur Mathelo in Sindh. 
He had nine daughters; one of them was Moomal (Damraho 2007), who was the most beautiful of all, while another was named Soomal, who was the cleverest one. She was also well grounded in magic and sorcery. Moomal had constructed a beautiful palace known as Kak Mahal on the bank of River Kak in Ludano. The palace was quite inaccessible. She put a condition that whosoever reached her in the palace, would marry her. In those days,Hamir Soomro was the ruler of Thar. He was fond of hunting. Rano was his friend and wazir (Damraho 2007). As Hamir heard about the beauty of Moomal, he decided to get her but he could not reach her. Rano was very wise and intelligent who reached her and got her. When Hamir came to know about this, he imprisoned him. Rano was released on the condition that he would not go to see Moomal, but he usually went to her in night and came back before the dawn. Later, he could not visit her for a long time. Moomal was desperately longing for him, so she asked Soomal to dress up as a man and share bed with her, so that she could get fragrance of Rano. Rano came by chance and saw a man in Moomal's bed. He got so angry that he never returned back (Shad 1992). Bhitai pointed out the ego of man and the love of Moomal in these words:

"Putting me in torture, Rano himself rests in Dhatt, Last night some secret hint Rano has left, Without Rano, friends! I have no peace, yet I lose not hope that he will return and my yeaning cease.

"Rano, the path by which you come, I daily watch, within me lie ties of your pleasant talk, Nails of love have riveted me to you." (Khamisani, 1977: 159)

The jagirdars enjoyed immense social and political power, while the zamindars occupied the position of honorable middle class. The zamindars played an important part in the social system. They paid the revenue and made regular early payment to the cultivators. They enjoyed a large number of feudal privileges in lieu of their services. In some places the kings elected the zamindar as a representative for the management of public affairs. He was called Mukhadam or Arbab (head of village or respective tribe), a title which is still used in Sindh. (Sorley, 1989)

Bhitai writes:

"Sailor! You cannot profit both ways, you sleep the whole night beside the helm, tomorrow you have to give account, how you spent your days. "I traded with glass not with pearls I bought tinsel of no worth, with all these faults, your grace I crave.” (Khamisani, 1977: 56)

Bhitai pointed out the art of the fisherman that how they understood the River Indus as well as the sea. He also highlighted the hard work and commitment of the divers, who were expert in diving and had great insight into the flow of river water (Shad 1992). 
"Divers alone know the art of ocean's search, Diving into its depth, they found precious gems of worth; With their own hands, gems of worth, they brought forth" (Khamisani, 1977: 58)

After analyzing all these stories, it evidently appears that the folk literature of Sindh is uninterrupted continuity of oral tradition embellishing the epic and its narration which makes it not only a significant contribution within the domain of folklore but also a valuable source of information on the historical and cultural aspects of the region. In absence of any contemporary record of this period with the exception of a few passing references in some historical works, this epic in its different dimensions become a valuable source of information to the historians to piece together a more valid account of the political, social, cultural, economic and ethnological conditions of Sindh during the twelfth to fourteenth century.

\section{Conclusions}

Viewed from within, from the perspective of the historian at work in a community, all histories are history. Simply, folklore is what we call other people's history. It is actually the history confected in the little community of the academy. (Glassie, 1987) A minor difference between the folklore and academic history is to be found in the medium of communication. The major differences between them abide in the culture of historian. From deep in their cultures, historians extract an idea of the real, which forms the basis of their description of action. Actually, history is culture. Different cultures shape different histories. Without resort to falsification, historians select different facts and arrange them differently because historians live in different societies governed by different needs. Accepting the challenge of folk history and the opportunity of the artifact, we have a chance to co-operate in the construction of history that will entail the truth in all histories that will embrace multitudes.

The folklore which is employed as a source for compilation of the earliest written record on history of Sindh enables us to understand different perspectives of the society. Particularly the character of woman, each of them is distinct, having different attributes and qualities. These qualities are loyalty, patriotism, endurance, fearlessness, steadfastness and intellect. Her natural flaws and weaknesses are also exposed from these stories and provide a complete picture of her individuality which provides help in understanding her role in the society.

All women characters express some social, cultural and moral values of the place and time as well as the psychology of the people of that era. The message of freedom and patriotism is found from the story of Marui. Importance of this feeling is felt when the 
country faces problem. As this record was narrated during the Kalhora period (1737-1783 $\mathrm{CE})$, there was a need to ignite such a feeling among the people in that deteriorated economic, political and social conditions of the oppressed people. However, the woman must have had to strive to get the attention and love of her husband. She had to strive to excel herself in the art of monopolizing the polygamous husband. The stories of LeelaChanesar, Moomal-Rano and Noori-Jam Tamachi are evidences in this regard. The folklore of Sindh, though considered being fundamentally fictitious but it is important and significant as the only historical source that provides an image of social set up of the past era. During this era, love, loyalty, and the qualities of chaste woman are glorified but she was a victim of social inequality and injustice. Narrators depicted the picture of woman as they wanted her to remain in the society with a pure and chaste character.

The attitude of a society towards its women is an indicator of the extent of its decency. In the folklore, the attitude towards woman shows two distinct traits. One, the actual status of a woman in that feudal society and second, apart from the actual position it represents ideal of a perfect woman. So, in order to give her lost status in the society, the woman of the time was given so much importance that her emotional state was also being considered because of the fact that she was a representative of suppressed and suffering class. There was a need to make her feel sympathy in order to give her deserved status in the society. These characters express the feelings and emotions of different types of women which provide an opportunity to analyze the causes of disruption of the society.

Folklore is uninterrupted continuity of oral tradition embellishing the epic and its narration which makes it not only a significant contribution within the domain of folklore but also a valuable source of information on the historical and cultural aspects of the Soomra period. In absence of any contemporary record of this period with the exception of a few passing references in some historical works, this epic in its different dimensions becomes a valuable source of information to the historians to piece together a more valid account of the political, social, cultural, economic and ethnological conditions of Sindh during the twelfth to fourteenth century.

\section{References}

Allana, G.A. (1977). Lar Ji Adabi Aen Saqafati Tarikh (Literary and Cultural History of Larr). Jamshoro: Institute of Sindhology.

Baloch, N.A. (1999). Sindhi Boli Aen Adab Jee Tarikh (The history of Sindhi Language and Literature, Jamshoro: Univrsity of Sindh.

Baloch, N. A. (2003). Sindh: Studies Historical, Jamshoro: University of Sindh. 
Baloch, N. A. (2014). Folklore of Sindh: Anthology of Prefaces. Karachi: Culture Dept. Sindh.

Bhitai, Shah Abdul Latif, (1975). Shah jo Risalo, Eng. tr. Amena Khamisani. Jamshoro: Institute of Sindhology.

Damraho, Badar, (2007). Latifee Encyclopedia, Kandiaro: Roshni Publication.

Doctor, R. (1985). Sindhi Folklore: An Introductory Survey. London: Taylor and Francis Ltd., 96(2).

Glassie, H. (1987). Folklore and History, Journal of Minnesota Historical Society. Minneapolis: The University of Minnesota, vol.50:5.

Khan, Khan Bahadur Khudadad. (1959). Lubb-i Tarikh-i Sindh, ed. Dr. Nabi Bakhsh Khan Baloch. Hyderabad: Sindhi Adabi Board.

Palijo, Rasool Bux, (2015). Tanee Mank Merya, Kandiaro: Roshni Publication

Saleem, M. A. (2004). Folk Music in Sindh, Quarterly 'Kalachi'. Karachi: University of Karachi, vol.7:4.

Shad, Bashir Ahmed, (1992). Arfan Latifee, Shikarpur: Mehran Academy.

Shaida'i, Rahimdad Khan Mawla'i. (1985). Jannat al-Sindh. Hyderabad: Sindhi Adabi Board.

Sorley, H. T. (1989). Shah Abdul Latif of Bhit. Karachi: Sindhi Kitab Ghar.

Syed, Durre Shahwar, (1988). The Poetry of Shah Abul Latif. Hyderabad: Sindhi Adabi Board.

Bashir Ahmed is Lecturer in the Department of General History, University of Sindh, Jamshoro-Sindh.

Dr. Humera Naz is an Assistant Professor in the Department of General History, University of Karachi. 